\title{
An ecological settlement design for refugees in Kocaeli
}

\author{
Merve Küçük ${ }^{1,}{ }^{\text {, }}$, Tülay Tikansak Karadayi ${ }^{1}$ \\ ${ }^{1}$ Faculty of Architecture, Gebze Technical University, 41400 Gebze/Kocaeli, Turkey
}

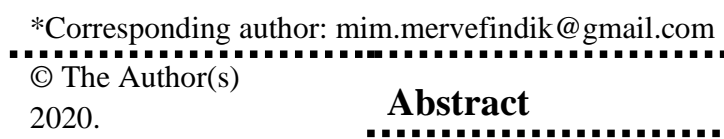

Keywords: Kocaeli/Turkey, Refugee, Ecology, Ecological living unit, Ecological settlement.

\section{Introduction}

Due to exceed three million number of registered refugees, shelter and source of all problems in Turkey are also seen. The literature screening of refugees in Turkey has been seen that there is a lot of work on the sociological effects. In addition, its environmental and architectural impacts cannot be underestimated.

The high in terms of residential energy needs in Turkey and the number of migrating refugees increases with each passing day increasing energy requirements, organized by the use of urban existing energy, water, 
resources such as infrastructure starts to come inadequate. Tent cities or container cities arranged for refugees are located in cities close to the border and long-term comfort conditions are insufficient. It is observed that short-term housing solutions that refugees find with their own means are also insufficient. For this reason, the study started with a questionnaire in order to get to know the refugees living in Kocaeli, which is a user group. In this survey study, refugees' needs such as shelter, transportation and environmental awareness were questioned. Criteria such as ecology of the study, providing workplaces and food supply by providing agricultural areas to refugees, recycling wastes and using renewable energy sources have directed ecological settlement design. In order for the ecological settlement to be applicable, a sample region was chosen by taking the opinions of Kocaeli Metropolitan Municipality. The climatic and environmental characteristics of the region have been examined, and the selected land has been divided into functions according to vegetation.

The purpose of this study; is to create a settlement that integrates with the nature and fulfills its own needs by solving the need for the accommodation of the user in emergency situations as soon as possible. The ability to live in small spaces acquired in emergencies, to use less items and less products, has been combined with ecological settlement principles and has become a comfort criterion. Apart from the application areas in emergency situations, this project is also applicable for the people with low income, employment in terms of sustainability of the green area or for those who will migrate by choosing rural rather than the intensity of the city life. This study is intended to be a resource for later studies.

\section{An Ecological living unit model}

The number of refugees in Kocaeli is increasing day by day. While the number of Syrian refugees in Kocaeli is 34.146 in 2017, it has become 46.186 in 2018. According to the statements made in 2019, the number of refugees registered in Kocaeli has increased to 56.786. Demographic data show that the number of registered Syrians in the province has increased by 22 thousand 640 in two years [1].

Kocaeli is preferred because it is one of the industrial cities and there are many job opportunities. In addition, since it is not as difficult and expensive as the living conditions in Istanbul, it is easier to find housing, safe living, education and health in neighboring Kocaeli.

Refugees, asylum after to Turkey are trying to regain pre-war living standards. Refugees who cannot meet their daily needs due to life threats and leave their countries are not completely safe in a foreign country. This is because; Inability to express themselves because of not knowing the language while trying to be included in the society, the work environments are unhealthy or dangerous, and the minimum comfort conditions cannot be met in the living areas. In this section, a model has been created for refugees, a living space that protects the environmental values, complies with the environmental data of the region and also respects the expectations of the users.

While taking sectoral steps with ecological awareness to reduce natural resource consumption all over the world, the requirements such as shelter, work, transportation for refugees should be resolved with ecological criteria. With this idea, an eco settlement area, where refugees' shelters are provided from ecological living units and urban agriculture areas as much as possible, should be created. Energy needs must be supplied from renewable sources, transportation must be by zero-emission bicycles or scooters or on foot.

\subsection{Features of Kocaeli}

Various features of the region are an important determinant in the design decisions to be taken for the ecological settlement model to be designed in Kocaeli. Therefore, climatic, environmental and sociological features related to the selected sample area are examined in the following sections. 


\section{Climatic data}

Kocaeli climate is a transition climate between the Mediterranean and the Black Sea climate. Winters are partially warm and rainy, summers are hot and rainy. When snowfall is evaluated, the duration of the soil covered with snow is maximum 10 days. Annual rainfall varies between $768-1153 \mathrm{~mm}$ by region [2].

The climate of the province of Kocaeli is warm and moderate. There is significant rainfall due to the effect of this climate. It is a region that receives precipitation even in the hottest months. The climate is $\mathrm{Cfa}(\mathrm{C}$ : warm temperature; f: fully humid; a: hot summer) according to Köppen-Geiger as in Figure 1. The characteristics of the Cfa class climate are that it is warm in winter, summer is very hot and rainy in all seasons [3]. The average annual temperature of Kocaeli is $13.9^{\circ} \mathrm{C}$. The average annual rainfall is $848 \mathrm{~mm}$ [4].

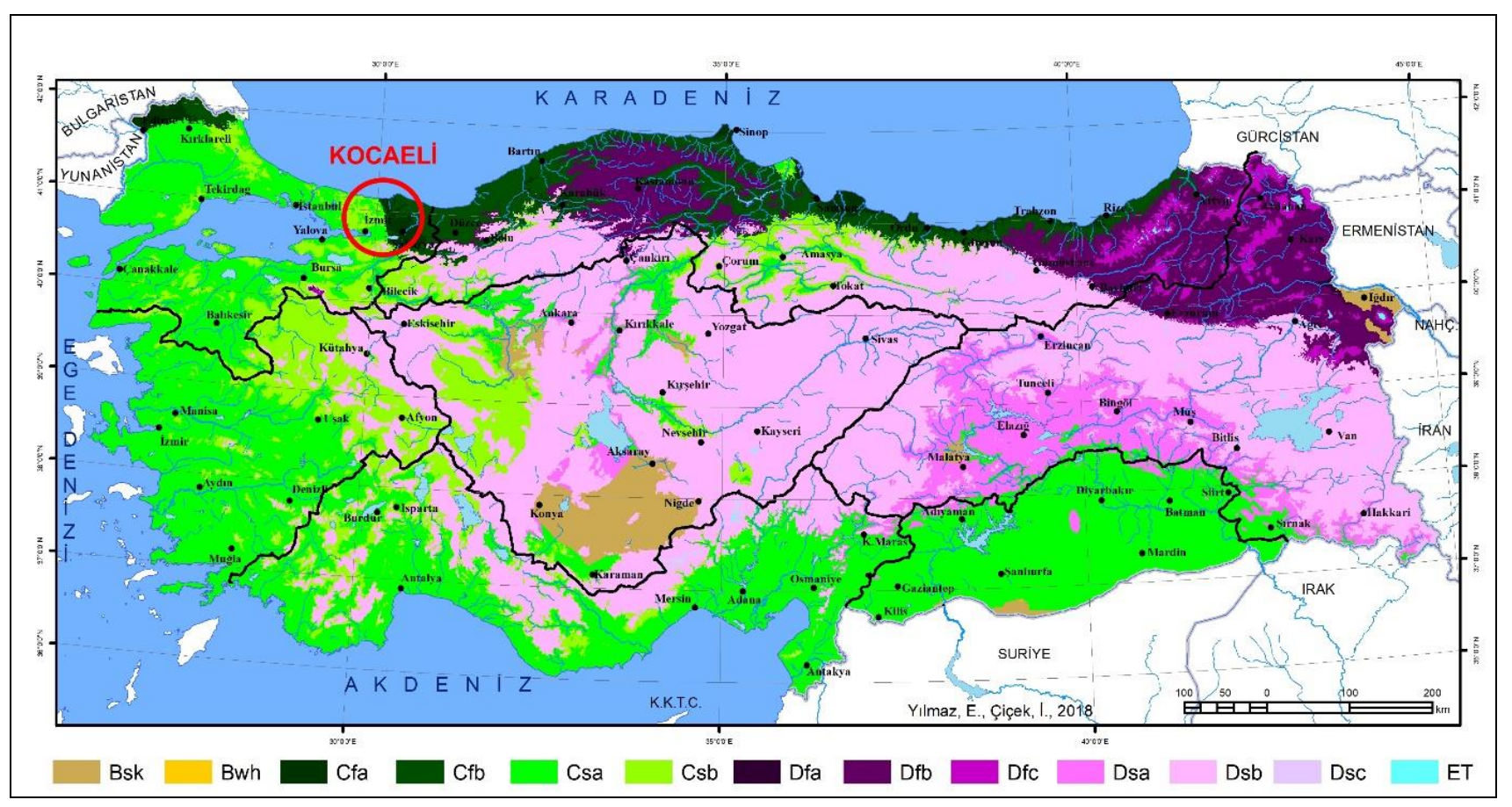

Figure 1. Köppen climate classification in Turkey

While average sunshine duration is 9.6 hours in summer in Kocaeli, it reaches at least 2.5 hours in winter. The average number of rainy days per year is 133.2 days. Considering the data related to Izmit district of Kocaeli, it is the driest month of July with $42 \mathrm{~mm}$ of rainfall. With an average of $121 \mathrm{~mm}$ of precipitation, the most precipitation occurs in December. The annual average summer season temperature is $23.8^{\circ} \mathrm{C}$ and the winter season temperature is $6.2^{\circ} \mathrm{C}$ [5]. The primary dominant wind is the "Star" from the north, and the secondary dominant wind is the "Lodos" from the south west.

\section{Vegetation}

When the vegetation in Kocaeli is examined, it is seen that the mountains are covered with forests. The green texture of the Kocaeli region consists of $60 \%$ forest, shrub, scrub, olive grove and poplar, $30 \%$ agricultural areas, $7 \%$ meadows and pastures. The part covering only $3 \%$ of the region is not suitable for agriculture. Vegetation has the characteristics of Mediterranean and Black Sea region [5].

Turkey's most important industrial and commercial centers which are capable of being one of Kocaeli, ranks 10th in terms of population density. It has been observed that the province gained an industrial city identity starting from the 1950s, its population increased rapidly and the natural habitats were exposed to intense 
construction. Despite this, it has been determined that the plant species seen in Kocaeli with a wide variety of plants are around a thousand [6].

It shows that the plant diversity in Kocaeli is quite wide and its soil is suitable for plant growing. In line with all these data, it was concluded that the soil is suitable for the ecological settlement, which is planned to be carried out in urban agriculture.

\section{$>$ Sociological data}

After the migration intake in extraordinary situations, slum settlements began to occur around Kocaeli, which caused negative impact on infrastructure systems and urban resources. Slum settlements, which cannot be fused with the city, have been grouped within themselves and the culture of nursing has also taken place in the neighborhoods. This grouping prevents urban consciousness and belonging to the city. With the combination of employment need and cheap manpower, which basically exists in Kocaeli, a class difference has begun to emerge in the city.

\section{$>$ Kocaeli environmental problems}

Turkey's population with an increase of the current intensity of the overall construction increased environmental problems thus reduced green space, inadequate infrastructure has started to arrive, the increased consumption of natural resources and environmental pollution. As it is an industrial city in Kocaeli, air pollution is observed especially in districts such as Dilovası and Gebze. However, in 2017, Diliskelesi in Dilovasi suffered damage to water birds and many sea creatures due to the fuel oil leak. With this leak, both the sea surface and the bottom of the sea are contaminated, and the living space of sea creatures has been destroyed. In order to avoid similar accidents and negligence, measures and inspections should be increased by authorized units.

In some residential areas of Dilovas1, which are heavily exposed to air pollution, it is determined that human health is negatively affected. Moving the neighborhoods related to this issue, increasing the air quality and quality of life has been put on the agenda by the authorities.

Fossil wastes, industrial wastes, domestic wastes and the density of transportation are environmental problems that municipalities are trying to solve. Waste collection and management planning has been made for 12 districts of Kocaeli. In Kocaeli, a facility that provides recycling of domestic and industrial wastes has been established in Dilovası OSB for the control and evaluation of many wastes, as well as measuring stations where air and water values are monitored in order to protect environmental resources. In addition, Gebze wastewater treatment plant was established, and the wastes seen before were prevented from reaching the Gulf of Izmit via streams such as Dilderesi [7].

\subsection{Refugees' housing problems}

Refugees, after arriving in Turkey near the Syrian border on the move continue their life in tent cities and container town in the province or continue to reside in any province by their own means. Refugees who have to find their own housing accept to live in bad conditions, and with this situation, refugees work in uninsured and unsafe conditions in their jobs.

Refugees need to live in safe living spaces and maintain their lives in a healthy way. It is very difficult to struggle to survive in another country, in another language, at an unknown time. 
Refugees' sense of belonging in the ecological settlement is important for adaptation to the ecological lifestyle. For this reason, rural housing architecture in Syria has been generally examined. To become Turkey's borders with Syria and be in cultural interactions through history is also reflected in the residential architecture. Its narrow and small-sized windows, iwan, portico, different plan settlements with inner courtyards are similar to traditional Turkish house typology (Figure 2).

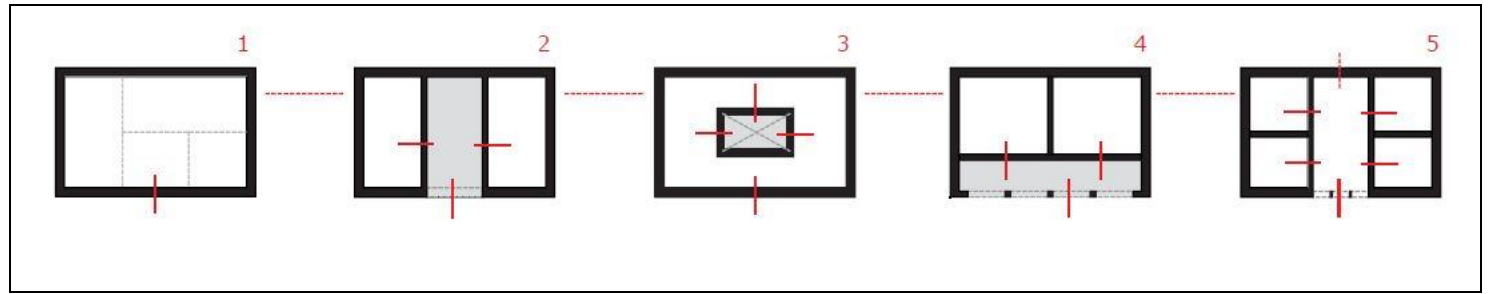

Figure 2. Outline of Syrian residential architecture

Housing plan types seen in Syria are as follows.

- Basic or closed rectangular house

- Liwān house

- Courtyard house

- Riwāq or gallery house

- Central Hall or Lebanese house [8].

In the design process, Syrian residence architecture plan types were examined, and climatic and environmental factors and cultural factors were taken into consideration in the design of the ecological living unit. The issues that refugees attach importance to in their housing preferences in Kocaeli are as follows;

- Rent

- Close to school (if there are children)

- There are places such as a market place where cheap shopping can be done nearby.

As can be understood from these criteria, when choosing a house by refugees, the properties and comfort conditions of the house are not considered. However, the task of the designer is to provide adequate comfort conditions for the users in the building, along with other criteria, at the same time, to realize sustainable designs that do not harm environmental values and have low environmental impact. As the opinions and expectations of the users are also considered in the design, it was decided to conduct a survey study that includes the refugees' expectations from the housing, the needs of the residence and environmental sensitivity to create a healthy settlement area. This survey study has directed the designed ecological area.

\subsection{Survey work}

As in all provinces of Kocaeli in Turkey around 50 thousand refugees are living. The survey conducted with refugees in Kocaeli revealed that some families first settled in Istanbul, but came to Kocaeli after a while on the recommendation. When Kocaeli and Istanbul are compared; It is thought that living in Kocaeli is safer and more economical. Since the transitions of refugees between provinces cannot be controlled, the number of refugees is increasing day by day in Kocaeli.

The city center and the districts close to the center are preferred. A charity was contacted to observe the refugees 'accommodation and the refugee families' houses were visited with a Syrian translator.

While the various expectations of the user are met in the ecological settlement to be designed, it is aimed to have environmental features and to meet the food needs in this area by making urban agriculture. For this 
purpose, a survey was conducted to get to know the refugees who have a user base, to observe the houses they live in, to investigate what is expected from the housing, to what extent the needs are met and to see if they want to be in such an ecological settlement. In the survey, 40 families were interviewed, including 10 families from each district in Gebze, Gölcük, and Kartepe and Izmit, which are among the districts where refugees are concentrated. The questionnaire was also asked to users to understand their environmental sensitivity. In this survey, questions were prepared under the following topics.

- Questions About Housing

- Comfort Features of the House

- Environmental Features

- Satisfaction from the Housing

- Environmental awareness

As a result of the survey conducted to determine the needs of refugee families in Kocaeli, it was determined that $47 \%$ of the refugees who were surveyed have lived in Kocaeli for 1 year and less. This means that the number of refugees in Kocaeli has increased in recent years and the refugees who have arrived have encouraged relatives and acquaintances to come to Kocaeli. It has been observed that the houses where the refugees live and found by their own means are not satisfied with the features such as heating, size and lighting (Figure 3).

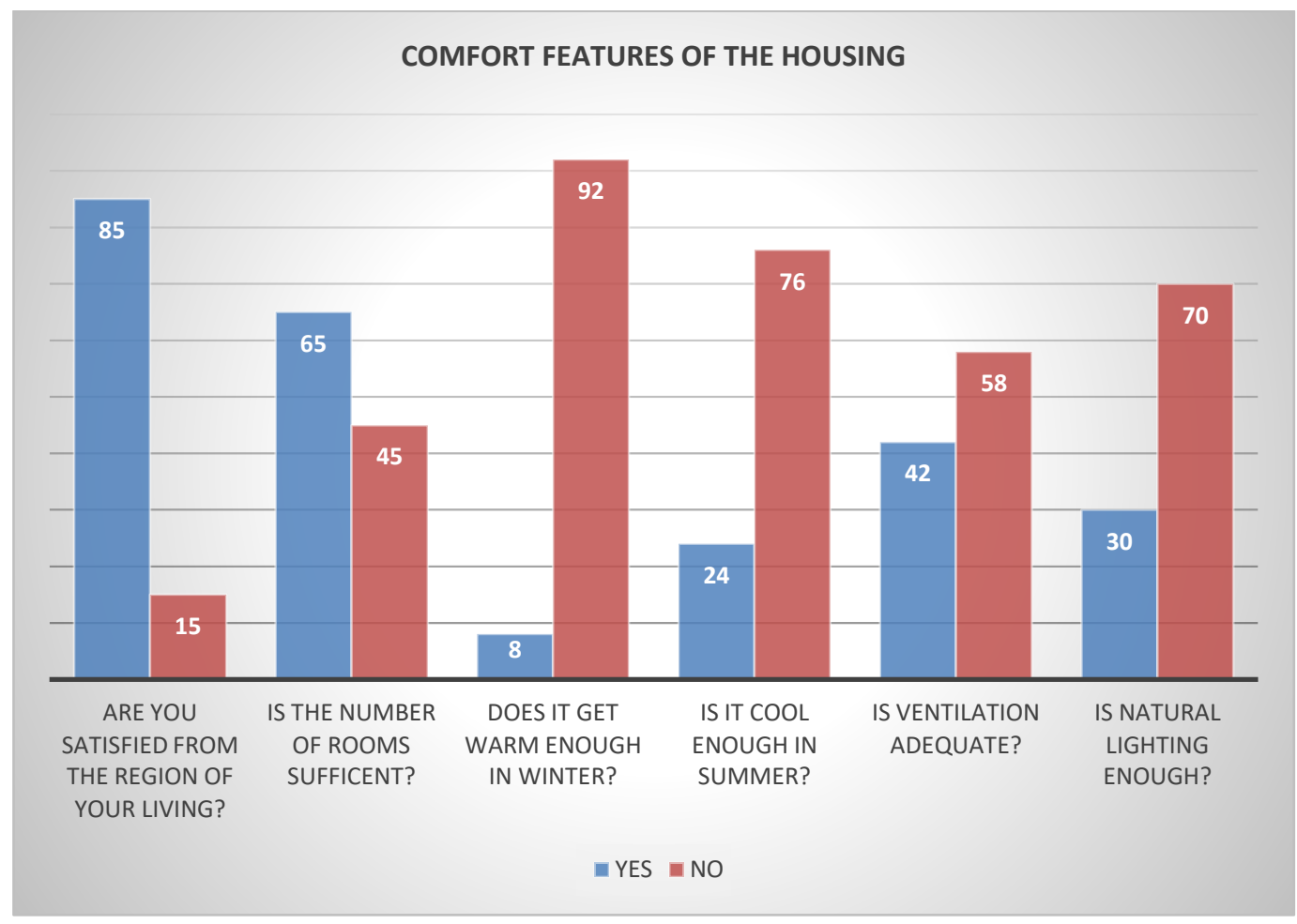

Figure 3. Comfort properties of the refugees' residences [9]

In this survey study, it is understood that refugees have information about the use of $100 \%$ renewable energy sources in houses and recycling of household waste. Refugees who migrated from Syria's cities such as Aleppo, Hama, and Raqqah, which were farmed, were interested in agriculture. Considering the educational status of the refugees who participated in the survey, it was understood that 35 people were secondary school graduates, 3 were high school graduates, 1 was a university, and 1 was a primary school graduate. It is thought that urban agriculture may be appropriate in terms of employment, taking into account the educational status of refugees together with environmental data in the ecological settlement area. All of the refugees welcome the idea of ecological settlement, which is planned to be created for refugees. 
There are 100 ecological living units in the designed ecological settlement area, this number may increase or decrease depending on the intensity of use, and accommodation opportunity for approximately 400 people can be provided. A part of the food supplies can be met through urban agriculture, and the excess product obtained can be sold in the organic food market. It is important for refugees to have knowledge about the systems used in the settlement area, to ensure that the families living in this region comply with the social and ecological rules of the settlement, to ensure the sustainability of the ecological lifestyle. Ecological living units are therefore a system consisting of basic living spaces that can be expanded by combining additional modules according to the need. The compact amount of these units consisting of simple, geometric form will reduce the amount of energy needed [9].

\section{Ecological layout design}

In Kocaeli, the results of the questionnaire study applied to the users to determine an appropriate, ecological settlement area for refugees and the environmental data of the region were evaluated and the decisions described below were taken.

https://hsd.ardascience.com/index.php/journal/article/view/40

\subsection{Determination of Settlement}

Environmental data about Kocaeli are given in the previous sections. Various micro properties and environmental data of the study area should also be known for correct design decisions.

While determining the eco-settlement, the following features were taken into consideration;

- In Kocaeli, the general vital fiction of the city should not be affected.

- Should be close to public transport networks.

- There should be areas for agriculture.

- The project area should be surrounded by expandable reserve areas depending on the intensity of use.

- It should be close to public places such as health and school.

- The density of the structure should be low and regular.

With all these data, a sample ecological settlement was determined by conducting interviews with relevant people in Kocaeli Metropolitan Municipality. The selected region is located in the Çayırköy neighborhood of Izmit district, farther away from the city center (Figure 4).

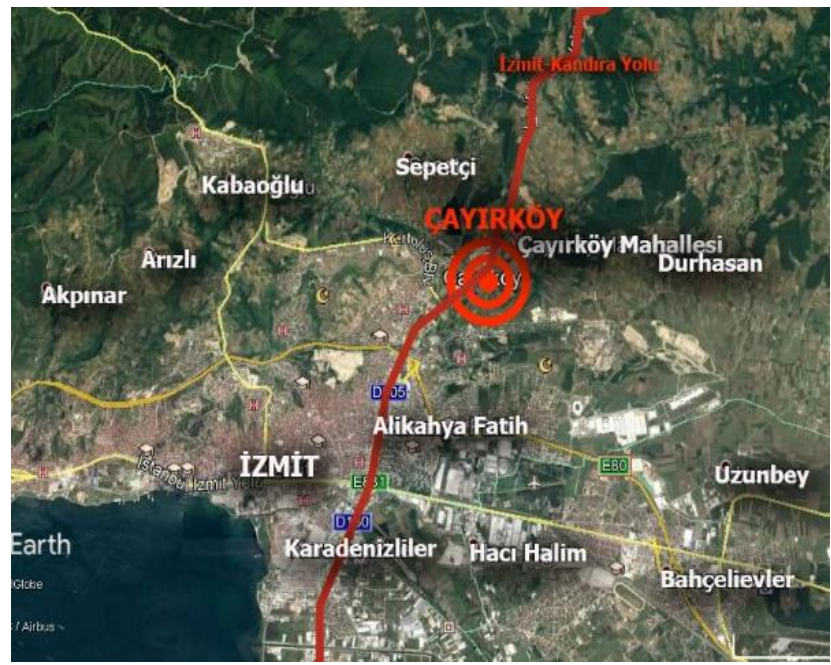

a)

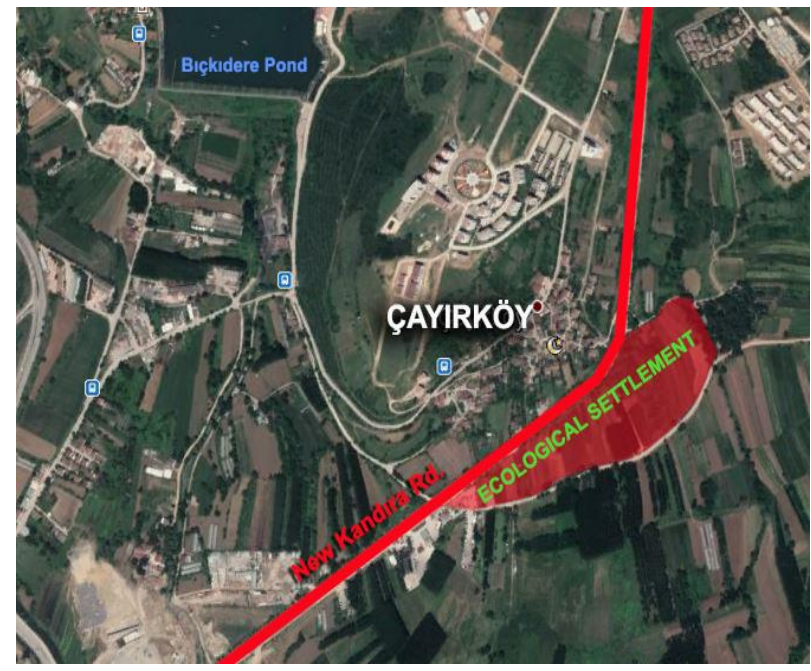

b)

Figure 4. Ecological settlement area location;

a) Location of the region in Kocaeli (Izmit), b) Location of the region in Çayırköy 
The designated ecological settlement is 15 minutes from the city center. It is located on D-605 highway. Its location on the main transportation axis allows emergency interventions such as ambulance, fire brigade as well as the use of public transportation vehicles. In order to reach the ecological settlement area, it is considered that the secondary road connected to the D-605 highway should be used actively and the transportation to the region should be carried out in a way that does not hinder the traffic. The selected region consists of many parcels. This is due to the fact that there is a mixed function land in the region where agriculture and zoning are done at the same time.

\subsection{Design decisions}

In ecological settlements, it is aimed that people reach their vital needs such as food, shelter, water, energy in a respectful way to natural cycles. In this study, a design proposal, which does not harm / protect environmental values, is aimed while meeting the accommodation needs of people in the chosen living area.

The reflections of sustainability on the settlements are diverse. While the Smart Cities mentioned in the second section benefit from technological developments to achieve the sustainable city ideal, Eco-villages aims to achieve this goal with traditional and natural methods.

Although all the settlement models mentioned constitute the planning principles for ensuring sustainability in environmental, social and economic aspects, the priority sustainability goal of each model changes. For example; While environmental sustainability is at the forefront in compact and smart cities; Eco-villages are also settlements where social and economic sustainability is as important as environmental sustainability [10].

In the design decisions to be taken for the ecological settlement to be created in the selected sample area, the following issues were given importance;

- Attention should be paid to the landscaping and protection of natural habitats, the climate of the region, the topography and the local texture in the design for the eco settlement, which is planned to be implemented according to the land surveys conducted in Izmit district of Kocaeli,

- Creating a spatial organization that allows variable use according to the season in the layout design and acts as a buffer according to the climatic changes, and organizing special semi-open and open spaces specific to the users,

- Energy efficiency by designing the building envelope and building form in accordance with physical environmental data such as sun, dominant wind, topography, climate, landscape,

- Energy conservation by integrating natural air conditioning systems and renewable energy systems into the structure,

- Providing the comfort features of the building with environmentally friendly, sustainable and recyclable materials,

- Evaluation of positive and negative aspects for reuse of rainwater and gray and black water, which are domestic wastewater, in order to ensure water conservation,

- To protect the ecosystem, it is aimed to protect the existing green areas, to use the soil efficiently and to make urban agriculture.

The following design criteria have been selected to be applied in the area selected according to the abovementioned objectives. At the end of the study, the applicability of these criteria was discussed.

\subsubsection{Compliance to local texture}

Due to its geographical location, Kocaeli has an industrial and commercial center, a coastal city and a growing city. In Kocaeli, especially Izmit province has been an important settlement area for different civilizations due to these geographical features throughout history. Izmit district is concentrated in the region near the bay and 
develops around dense transportation axes. The historical texture in the center of the district is not at a distance to associate with the ecological settlement area. The Çayırköy neighborhood, which is shown in Figure 5, is a developing but still rural area [11]. The ecological settlement area was designed with the idea of creating a prototype and preventing intense construction by preserving the characteristics of the rural area.

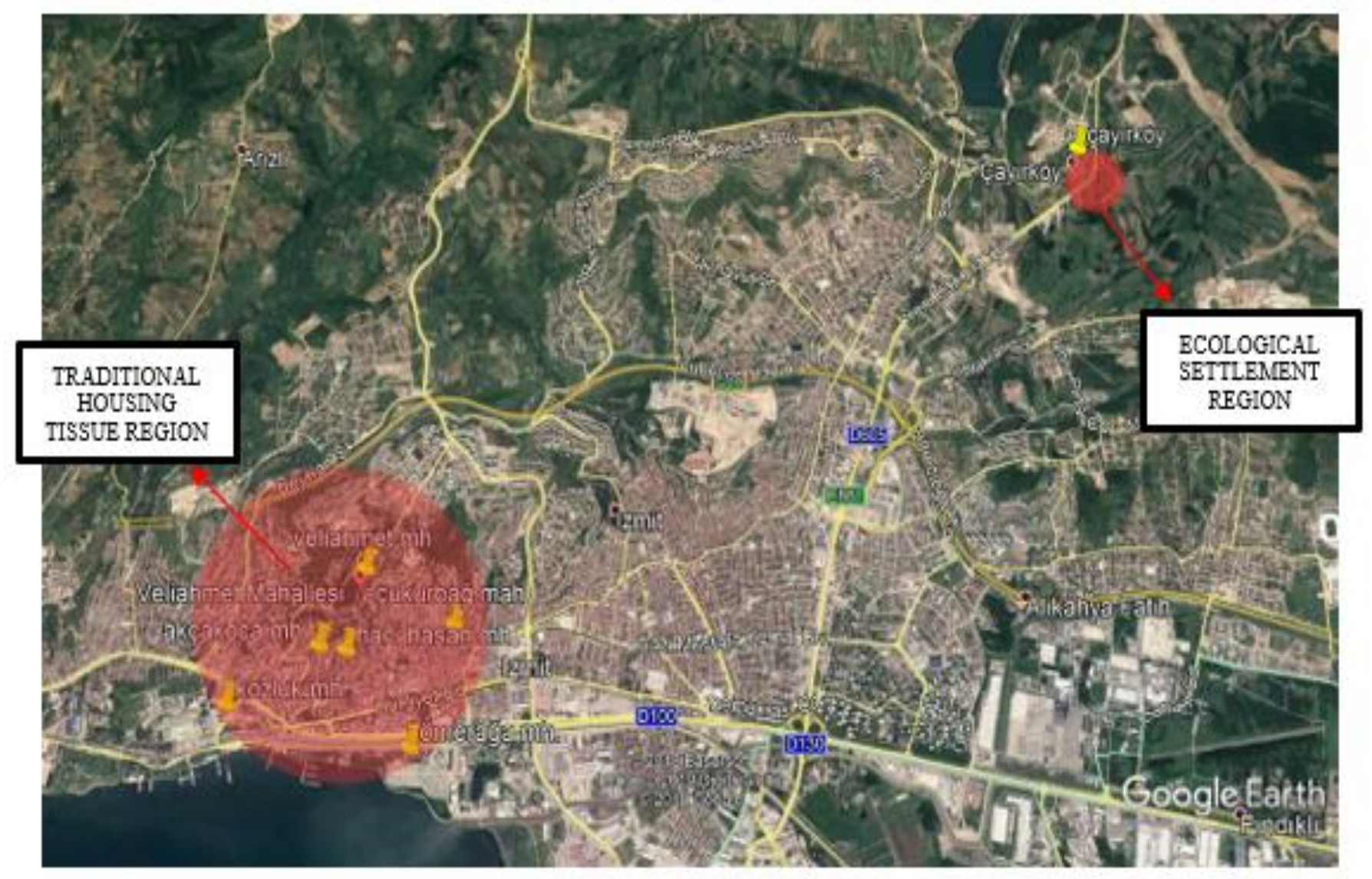

Figure 5. Kocaeli traditional texture and ecological settlement area

\subsubsection{Space organization}

In the ecological settlement to be organized in İzmit Çayırköy location, a flexible design is planned in order to expand / develop according to the needs and the size of the families in spatial setup (Figure 6). Therefore, it was aimed to ensure sustainability in the design with a modular and light materials construction system and reusable materials. Among the design principles that determine the spatial organization, it is thought that design according to the local culture, user health and efficiency, variable use according to the season, outdoor design applications will be suitable for the ecological settlement area. The design decisions taken for these applications are described below.

Ecological living units consist of a basic unit and additional rooms that can be added as needed. When adding a room, there should be another basic living unit with a room in its symmetry. If two rooms are added, it can be added to the base unit alone. This is necessary in order to keep the compact form intact. The unit that 2-3 people can use is $90 \mathrm{~m}^{2}$, the unit for 3-4 people is $109 \mathrm{~m}^{2}$ and for the 4-6 people it is $128 \mathrm{~m}^{2}$. In order to expand the ecological living unit, there are steel connection columns at the joints. The same expanding construction system that sits on the raised reinforced concrete foundation shoes is also suitable for wooden carcasses [9]. 

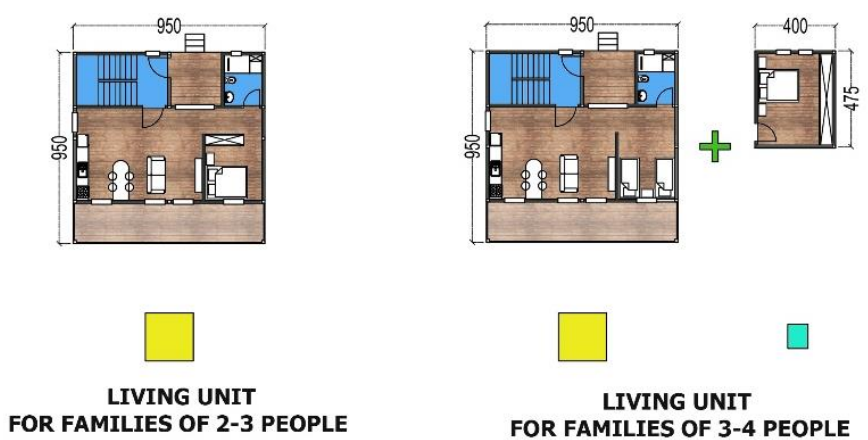

FOR FAMILIES OF 2-3 PEOPLE

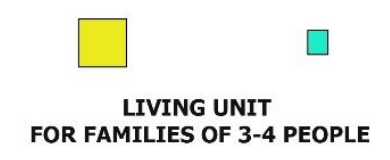

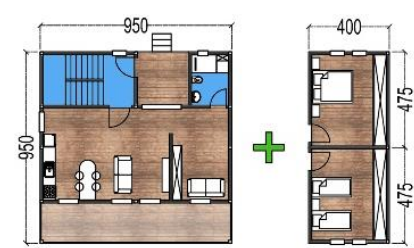

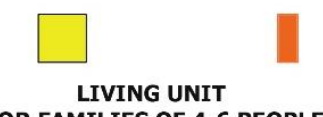

FOR FAMILIES OF 4-6 PEOPLE

\section{MAIN COMPACT \\ UNITS JOINT \\ SAMPLES

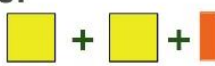

3MAIN COMPACT

UNITS JOINT

SAMPLES
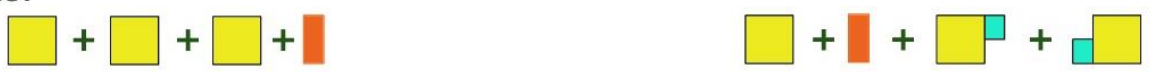

4MAIN COMPACT

UNITS JOINT

SAMPLES
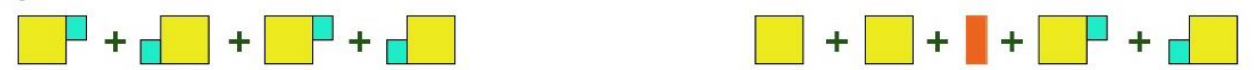

Figure 6. Ecological living units' flexible space organization charts

The ecological settlement has compact building plans (Figure 6). With this project, it is aimed to create functional components that can be formed as a prototype, increase in articulation with joints, and that are functional, adaptable and environmentally compatible [9].

In addition, issues such as design according to local culture, user health and efficiency, variable use according to the season, use of buffer space and special semi-open / open space design are also taken into consideration in the said ecological design.

\subsubsection{Energy conservation}

The energy efficient structure is the environmentally friendly buildings with the minimum greenhouse gas emission that minimizes the use of additional resources and provides energy savings by meeting the energy it needs from renewable sources.

When analyzed in terms of energy performance and design, the climatic features surrounding the outer environment of the building and the terrain conditions were analyzed, and the building form and user profile that determined the indoor comfort conditions were examined and their needs were determined. In addition, it is aimed that the building envelope will be capable of preventing the energy exchange between the interior and exterior environment, utilizing natural energy resources in proportion to the need and reducing the need for additional energy.

While creating an energy-efficient ecological settlement region, it is aimed to earn renewable energy resources through active and passive methods. Along with passive design methods, the use of state-of-the-art ecological methods in the region will increase the performance and transfer the excess energy to the network. Active systems applied in the ecological settlement area are as follows. 


\section{- Solar Cell}

The greenhouse walls and roof surface in the ecological living units will be covered with transparent solar panels. These technological transparent solar panels, which are still under development, consist of two glass layers with a thin film between them. The film between this sandwich structure converts sunlight into electricity as an active layer produced from organic molecules. In addition, this super thin film, which is organic, flexible and light, converts only light in ultraviolet and near infrared wavelengths into electricity (Figure 7). Therefore, it does not cut off the natural light of the window and does not dimming like on car windows [12]. Therefore, it shows a transparent feature. While transparent solar panels also function as windows, vertical surfaces also participate in electricity generation.

Panels mounted like glass convert only $5 \%$ of the light to electricity. This ratio is 3 times less than photovoltaic panels installed on the roof (efficiency of roof mounted panels is between 15-18\%). Transparent solar cells have been preferred because they can be used on wider surfaces by applying to windows, are aesthetic and are the material of the future being developed. It is thought that the energy obtained from solar panels will meet the daily electricity need and the excess gain is stored in the batteries in the ecological living units' control rooms.

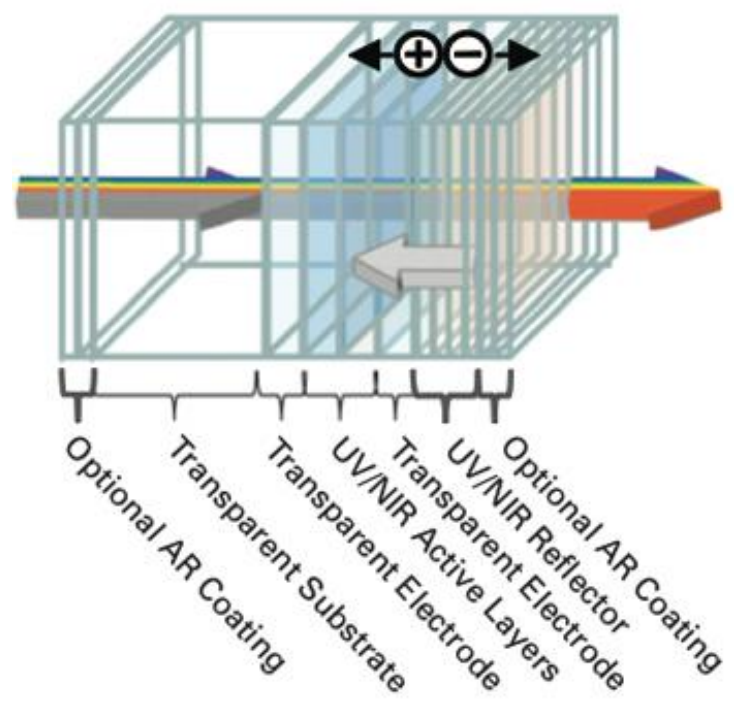

Figure 7. Transparent solar panel layers

In addition, issues such as heat pump, wind turbine, compact planning and compact form in the settlement, the use of natural air conditioning systems, building envelope design and sustainable transportation should be taken into consideration in ecological settlement design.

\subsubsection{Resource conservation}

For ecological layout design, energy saving and resource conservation can be achieved by correct positioning of structures as a result of topography, sun and climate analysis. However, natural resource conservation is possible with the use of durable materials, recycled material and local resource use.

\section{- Durable material use}

The ecological living unit is considered as an insulated wooden coating on a steel carcass. While both wood and steel are reusable, steel forming the carcass is a long-lasting and durable material. In the ecological living unit 
carcass, steel material was preferred considering that Kocaeli will be resistant to moist and abundant climate type. However, due to the high structure of the ecological living unit above ground, wooden carcass can also be preferred. The choice of materials, such as the construction system in an ecological structure, the transportation and transportation of materials, whether they are obtained from local sources, directly or indirectly affect the natural balance. While the carcass of the ecological living unit is preferred, the use of yellow pine, a local material on the walls, is preferred. The details of the wooden material are examined in the local resource utilization section.

\section{- Recycled material use}

Recycled materials as well as new materials in construction building materials are quite diverse and cover almost all of the building elements. Considering the comfort features in ecological residential buildings, it is considered to be used in recycled building materials, infrastructure and installation materials, facade and roof insulation, interior door and exterior environmental arrangement.

\section{- Local resource usage}

The peculiarity of ecological settlements is that the buildings are environmentally friendly in their life cycle. In the designed living unit, a wooden wall will be created on the steel carcass. This wall will be applied with glass wool material in the form of exterior cladding. Ecological living units have a high level of environmental sensitivity and are aimed to consist of materials that can be installed without polluting the environment in a short time.

The biggest advantage of wooden living units with steel carcass is that they can be completely removed and rebuilt if necessary. The design of these units may vary depending on the need and number of users. The most basic and important material of the unit is wood, which forms the outer shell. Careful selection of the wood used in these houses prevents future problems.

It is wooden pine to be used in wooden wall covering. It is applied on steel carcass. Scots pine or larch can also be used. Pine's moisture should not be more than 20 percent and rotten wood should not be used. Wood should not be too knotted. Knots should not be brought to the joints of the elements, unbounded, lowered knots can be removed and replaced with solid wood. Filler fibers to be filled in knots should be in the same direction [13].

Scots pine tree, western and southern slopes of the Eastern Black Sea in Turkey, in Eastern Anatolia and is frequently seen in South Marmara. Scotch pine trees cannot grow in arid climates, but it develops faster in suitable soils receiving precipitation. It is highly resistant to wind and cold. It grows in sandy and clay soils and requires intense sunlight [14].

While evaluating the environmental data, it is considered that the ecological living units are modular, can be used repeatedly, and a glass wool-filled wooden wall coating on the exterior is made on the steel carcass, which is sustainable. Each basic living unit is designed with a size of $90 \mathrm{~m}^{2}$. However, it has an extensible system feature if needed.

\subsubsection{Water conservation}

Water is a vital resource for all living things. The water, which decreases in the nature due to evaporation in the summer and regained as precipitation in the winter, cannot provide its natural transformation due to the wastes and pollutants caused by the human factor and the water resources become unusable. For this reason, it is aimed 
to reclaim under-treated water and rainwater by taking measures to reduce water consumption in the ecological settlement area by accepting that water is a consumable resource.

- Landscaping suitable for the region

In the landscape arrangement of the ecological settlement, local plants and trees growing in this region will be selected. Since such plants are suitable for the climate of the region, there is little need for irrigation. In this way, it can also contribute to water conservation. Among the trees suitable for this region, cherry, plum, linden, etc. It will be selected from tree species with edible fruits. Deciduous fruit trees will be planted on the southern facade, and evergreen coniferous trees, such as pine, will be planted on the northern facade, reducing the influence of the primary prevailing wind from the north. In order to protect the living life in the land and not to disturb the natural drainage, it is considered to use crushed natural stone coatings or permeable surface coatings held together with plants instead of impermeable coatings on pedestrian and bicycle paths.

The ecological settlement area is divided into three as partial housing area, poplar and agricultural area. While residential and commercial units are located in the area, which was previously a settlement, the agricultural area will be processed in accordance with the structure of the soil and poplar will be protected in the same way. Along with the agricultural areas, the green area will be dominant in the residential area, and private gardens and recreation areas will also be organized.

The user population is Syrian refugees and is intended to be as self-sufficient as possible within the ecological settlement. It is aimed that users make their living by making production through agriculture and maintain the ecological order by cultivating the soil.

- Waste water control

$75 \%$ of the water used in the houses in daily need constitutes the less polluted gray water. This shows that the water used can be recovered to a great extent. For this reason, natural recycling method will be applied in order to re-use rainwater and gray water and re-use in the reservoir and irrigate the garden.

\section{- Rainwater usage}

Since Kocaeli-Izmit district is very rich in rainfall, a hipped roof will be applied in ecological living units and roof gutters and rainwater will be transferred to the rainwater tanks of each unit. The excess of these waters will be collected in a pond created in the recreation area and evaluated for irrigation of the agricultural area.

- Gray Water-black water usage

A natural water treatment system will be established in the ecological settlement area, so that aquatic plants such as reed, reed, duckweed, water hyacinth, such as reed, reed, duckweed, water hyacinth, which will be created in the landscape arrangement by eliminating maintenance, equipment costs. In the purification system where these plants are used, while the plants are fed by consuming elements such as nitrogen, phosphorus, potassium and carbon that pollute the water, they will perform the purification process by transmitting oxygen from the air to the water through their roots. In this work, microorganisms in the natural environment contribute to the plants by feeding them with particles. While sewage water is treated to 'irrigation water' quality in the natural treatment facility, especially in villages, problems such as infectious diseases, flies, and bad odors arising from the treatment of wastewater to teas, streams or collection in septic tanks are completely eliminated [15]. 


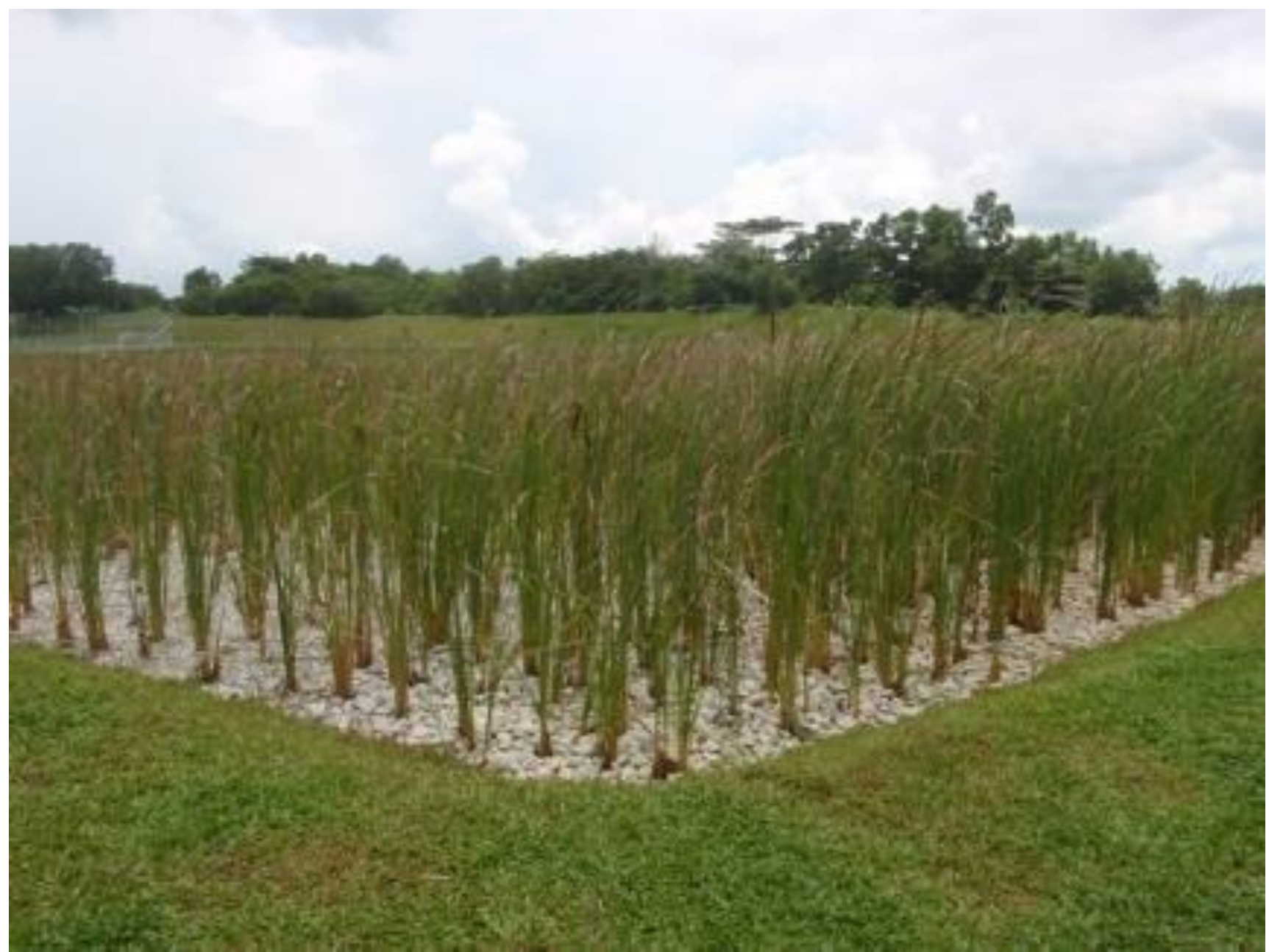

a)

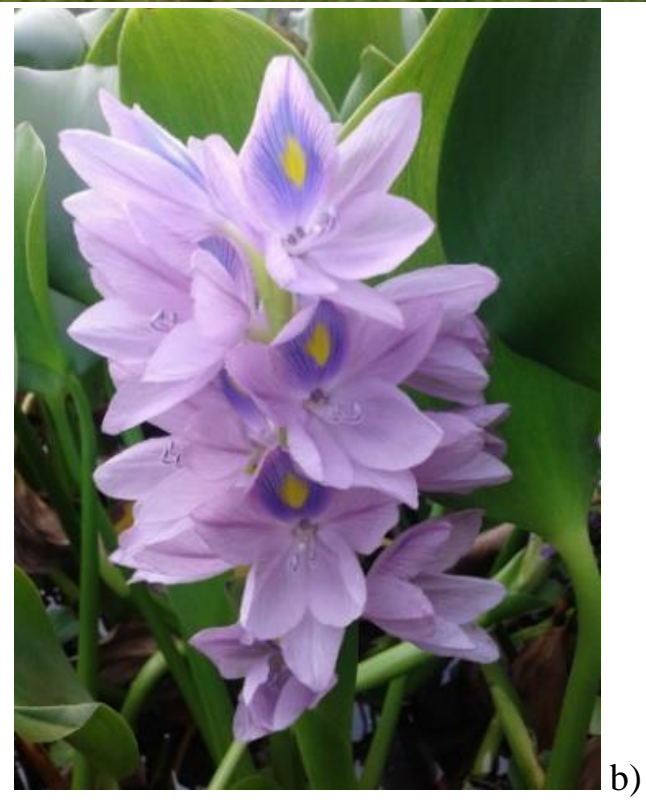

Figure 8. a) Subsurface flowing wetland sample, b) Water hyacinth

In the ecological settlement, a sub-surface artificial wetland will be created in which limited domestic waste water is discharged between the ecological settlement units in a compact structure. In addition, the plants that have a blooming feature, such as water hyacinth, will be part of the landscape arrangement (Figures $8 \mathrm{a}$ and $8 \mathrm{~b}$ ). Clean water separated from this region will be transported to the subsurface tank and will be used in garden irrigation when necessary [16]. 


\subsubsection{Ecosystem conservation}

The ecological settlement area should be in harmony with the natural environment in a way that does not disturb the ecological balance in any phase of the building in the selection of materials, construction and use. For this reason, it is very important to settle on the land and evaluate the properties of the soil. Conservation of natural life, protection of green tissue ratio, processing in accordance with the nature of the soil, and recycling of wastes that will occur during the usage phase of the building provide protection of the ecosystem.

- Protection of natural life

The Izmit / Çayırköy locality determined as the project land has been investigated in terms of the diversity of living vegetative species. Regions with no housing and less housing are separated. The eco settlement area will be located in the region where there are few unlicensed buildings. In the areas where there is no settlement, urban agriculture appropriate for the geological characteristics of the soil will be made. Since it is a region with temperate climates and a lot of precipitation, a hipped roof will be applied, and instead of gaining an ecological space with the roof garden, the minimum space on the land will be covered with the ecological living units removed from the ground. Living areas of living things will be protected by shrinking the area occupied by the settlement in the ecosystem. Roof slope will be evaluated with transparent solar cell panels, both energy will be produced and communication will be provided with the external environment. Care has been taken to ensure that the materials selected are natural and environmentally friendly [9].

- Protection of green tissue ratio

The purpose of ecological settlement is to protect the green area as much as possible. In order to maintain the ecological balance and take as little space as possible on the ground, the ecological living units will be lifted at a height of $50 \mathrm{~cm}$ to $120 \mathrm{~cm}$ depending on the slope of the topography with the steel feet. Raised flooring has many benefits. Providing rainwater drainage naturally from the building, no heat exchange with the ground floor, natural air flow under the ground, and humidity etc. undesired situations can be prevented.

- Efficient use of soil and urban agriculture

It is aimed to contribute to the livelihood of the user by cultivating in the area determined as the eco settlement area in Izmit district of Kocaeli.

The main agricultural products grown in Izmit are wheat, corn, sunflower, sugar beet and oat, as well as apples, grapes, beans and pears. Its land is very suitable for agriculture and animal husbandry and it grows in almost all kinds of fruits and vegetables in the region.

\section{- Recyclable waste management}

There are many types of recyclable products such as iron steel, copper, aluminum, lead, batteries, paper, plastic, rubber, glass, engine oils, waste oils, accumulators, vehicle tires, concrete, $x$-ray films, electronic waste, organic waste. Purpose for the collection, storage and recycling of waste in the ecological settlement area; is to evaluate and recycle wastes in ecological settlement.

The purpose of collecting, storing and recycling wastes is to ensure low energy consumption in ecological settlement, to save labor, to create environments suitable for health and to establish flexible pipe systems. However, it is not a settlement with sufficient density for such a waste collection facility to be installed underground. Since 100 families are a region where approximately 400 people live, it is planned to meet weekly [9]. For this purpose, it is planned to place wheeled waste collection boxes for organic waste, glass, metal, plastic, paper, electronic waste, and to deliver them to the waste collection unit at certain intervals (Figure 9). These waste collection bins will be located in the market place, the activity area and the ecological settlement, which are common areas of use in the facility. Recyclable wastes and wastes that reach the waste collection and inspection unit in the region are received at certain time intervals for recycling. 


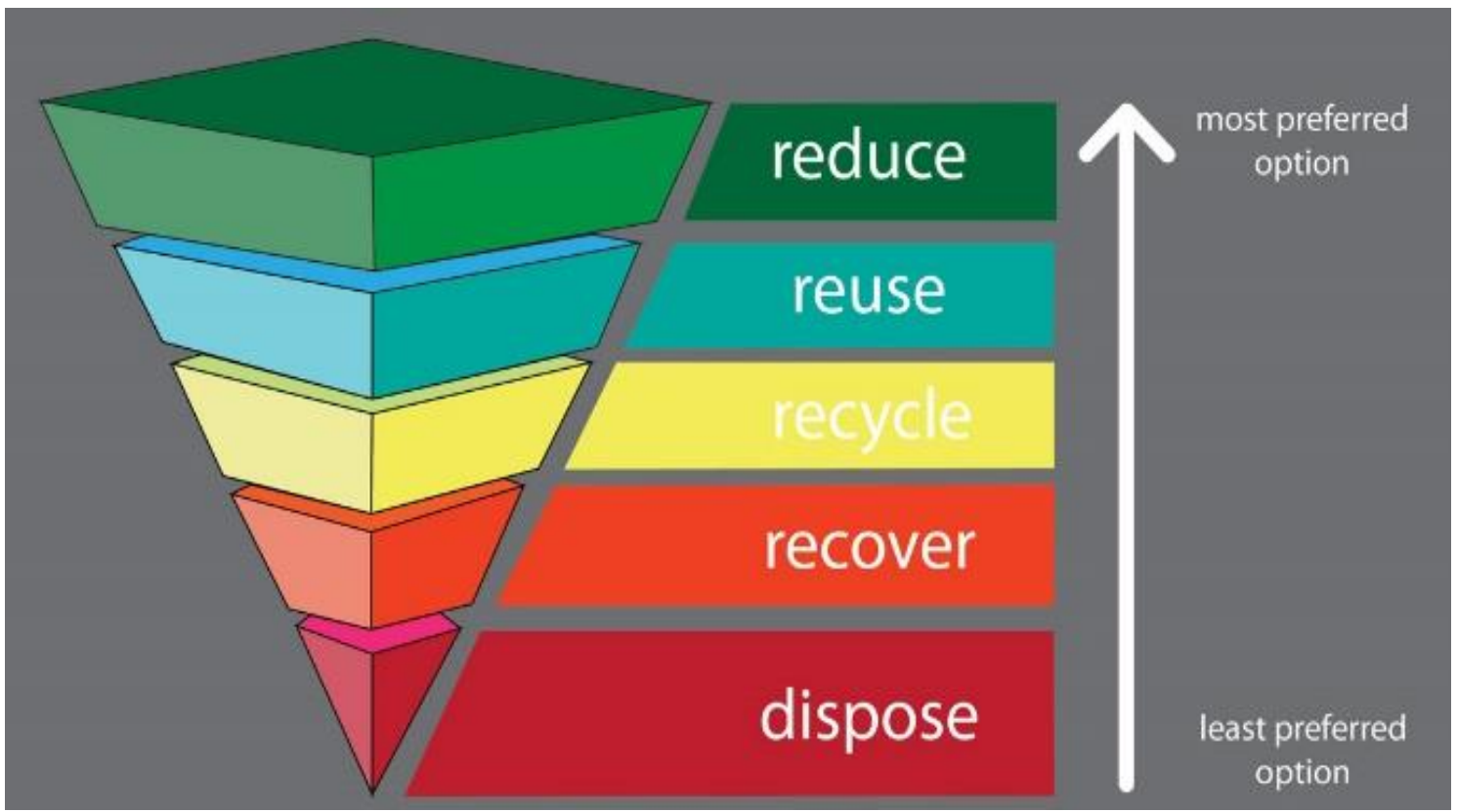

Figure 9. Waste hierarchy

As seen in Figure 9, the primary goal is to prevent or reduce waste generation.

\subsection{Ecological settlement area design}

The ecological living units are two-storey and there are living units on the south-facing front, while the north front has an entrance and wet volume. In the ecological living unit, all living spaces will benefit from natural lighting and ventilation.

When the standards related to window measurements are investigated (in The British Code BR 8206); For rooms with less than 8 meters' depth, it is suggested that the window area should be $20 \%$ of the outer wall area where the window is located for a sufficient brightness ratio [17]. Wind chimneys are not needed due to the large size of the windows in terms of lighting and ventilation.

Zero-energy building is targeted with renewable energy systems to be used in buildings that will be located in the ecological settlement. In this way, the building will be able to produce all the energy it needs. In the ecological settlement, passive air conditioning and heating decisions will be made, and the active renewable energy requirement consisting of mechanical systems will be kept to a minimum. Ecological living units are designed in a compact way in order to meet criteria such as heat preservation, energy saving, green space conservation. Ecological living units that will be applied in pairs and triples can also be applied in quadruples. Its common wall can be used as an installation wall, saving energy and materials. For this reason, it contributes to natural resource conservation.

Ecological living units consist of two parts, the basic living unit and the modular annex. The basic living unit will be able to provide suitable comfort conditions for families with two or three people with an additional room and for two or three people with an additional room. There is a glass greenhouse connected to each unit. Along with its functions such as seating area and plant growing, the greenhouse is located on the south-west facade and also features a sun room.

In the ecological settlement, which functions in Figure 10, the existing agricultural area, hazelnut and poplar areas will be preserved and used in the same functions. An artificial rainwater pond has been created to irrigate urban farmland and existing vegetation. It is planned to establish an organic food market where agricultural crops can be sold and to serve those living in neighboring plots [9]. 


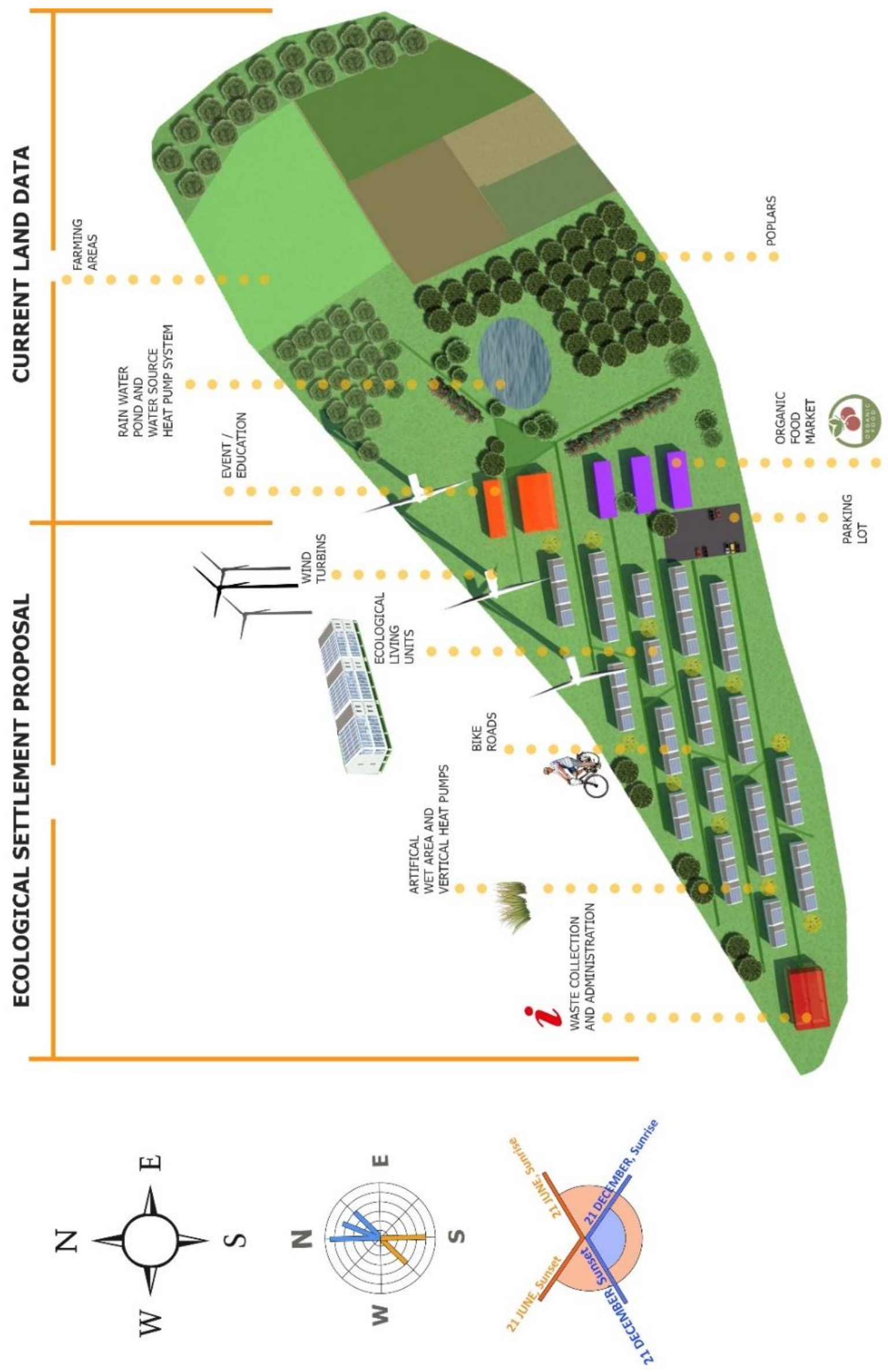

Figure 10. Location and function chart of ecological living units 
With the solar panel applied to the façade of the units, both the domestic electricity need will be met and agricultural irrigation can be done with increasing electrical energy. Irrigation system connected to solar energy will be able to irrigate from the stored rainwater pond to the agricultural area as a sprinkler or dropper [18]. In this way, excessive use of water will be prevented, and both water and energy can be saved.

\section{Results and evaluation}

The ecological settlement design should minimize the impact of the construction in the natural environment with all its decisions and practices and the selected materials. For this reason, the methods chosen may vary. One of the ecological design criteria is to create a green area as much as the area covered by the building, aiming to protect the habitat of living life [19]. For this purpose, roof gardens and raised floor applications on legs are observed in ecological designs. In Kocaeli, sloping roof was preferred instead of the roof garden in the ecological settlement due to the snow load. Instead, it was aimed to leave the least impact on the green area by designing a raised floor from the ground. Aluminum joinery and steel seam roof, where transparent solar panels are applied on the roof slope, will be used as this glass surface can continue at the vertical so that the surface obtained from energy can increase, functionality and aesthetic appearance can be provided at the same time. Heat insulated aluminum double glass joinery is preferred for door windows used in ecological living units. Instead of aluminum, PVC joinery can also be preferred to decrease the cost, and PVC material is a recyclable material like aluminum. However, considering the user health, aluminum joinery, which is a natural material, was preferred.

Designs suitable for climatic, topographic and geological data of the natural environment will greatly reduce energy losses. For this reason, appropriate construction system and building envelope should be selected together with cost analysis. In the ecological living units in the rural area, a raised floor covering with wooden coating has been deemed appropriate to adapt to the natural environment. Due to its longevity, recyclable and reusable features, steel carcass is preferred. Steel is a cost effective construction system with many positive features. Wood carcasses can be used instead. Since wood is a living material, deformities can be seen over time. It was not preferred with the idea that the wooden carrier material may not show sufficient comfort properties after deformations such as decay and stretching.

To ensure water conservation from natural sources, it has been suggested that rainwater should be collected in reservoirs and used as reservoir water, gray water should be treated in a horizontal surface flow artificial wetland with aquatic plants and used in garden irrigation. In addition, it is possible to make suggestions such as the use of water-saving double chamber siphon and the use of photocell faucets. These products were not used considering that they would increase the cost. Also, since the systems that provide black-water treatment are not commonly used systems, they are not preferred as one of the applications that increase the cost.

For the conservation of energy resources, orientation appropriate to the climate has been provided and the organization of the space has been designed. The building shell has been designed in order to benefit from passive ventilation and passive lighting in an adequate amount and to maintain the indoor comfort. Heatinsulated wooden cladding will be used on the building shell walls, and heat-insulated trapezoidal sheet material on the roof. In order to meet the hot water and heating needs of the ecological living units, it is thought to be provided by using vertical heat pumps originating from soil in the residential area. In order to meet the energy needs of the common areas, three small wind turbines have been placed in the region and it is planned to lay a water source air pump in the rainwater pond and meet the needs such as electricity, heating, cooling and hot water. 
In order to maintain air quality in the ecological settlement area, it is aimed to provide sustainable transportation by electric vehicles, bicycles and walking instead of vehicles using fossil-based fuel. In addition, the region is located on the transportation axis of public transportation vehicles. In emergency situations, it is possible to transport vehicles such as firefighters, ambulances and waste evacuation vehicles.

\section{Conclusions}

The settlement area has been determined as Kocaeli province, İzmit district, Çayırköy location by taking opinions from Kocaeli Municipality in order to have features suitable for ecological settlement. By evaluating the climatic, environmental and sociological characteristics of Kocaeli, the place of refugees in Kocaeli and their housing problems were addressed, and for this purpose, a survey was conducted for environmental awareness and renewable energy use by observing in the houses where Syrian refugees live. It has been revealed that Syrian refugees participating in this study have knowledge in systems that provide environmentally friendly energy and resource conservation. The survey showed that refugees can adapt to the living conditions set up in this area, such as the use of environmental systems in the ecological settlement, urban agriculture, cycling or walking and transportation.

In line with the data obtained, environmentally friendly, sustainable, recyclable or reusable material choices and ecological living units and urban agriculture areas were planned. This ecological settlement integrated with nature also shows a sustainable socio-economic feature such as support to agriculture, self-sufficiency with traditional village life, solidarity and sharing.

The choices made in the design of the ecological settlement have been evaluated considering the characteristics of the region. The region is considered as semi-zoned agricultural area in the plans of Kocaeli Metropolitan Municipality. For this reason, ecological living units have been designed on the raised floor, which will have the least impact in the region where there is a small number of unlicensed buildings, while preserving the existing vegetation and agricultural area. Artificial rainwater pond to be created in the settlement area has been considered important for irrigation of agricultural areas. However, since this pond does not exist in the natural habitat area and will be created later, this region can also be considered as an urban agriculture area.

Alternative products can be preferred in the project instead of structural choices that provide energy, water and resource conservation. With the choices made, active energy systems can be used to meet most of the energy need for ecological living units. Other renewable energy systems can be applied in the rate of efficiency obtained from wind turbine, soil and water source heat pumps and solar cells. Making the investment to renewable energy systems ensures that the cost is met over time and encourages the use of renewable energy systems in other projects and sets an example.

In the design of the ecological settlement area, instead of being a heavily used area, the green texture is preserved, the distance between the buildings is at appropriate dimensions and the gardens of the ecological living units are planned. The number of refugees that the ecological settlement area is thought to provide shelter environment is 100 families and about 400 people. This number is far below the number of refugees registered in Kocaeli. The reason for this is the targeting of the ecological lifestyle with shelter in the region. It is considered that there are agricultural areas and green tissue in the study area, thus urban agriculture can be done. In addition, solutions such as providing water treatment in the artificial wetlands considered in the region, forming a rainwater pond limit the residential area. However, regions located around the ecological settlement area can be considered as a suggestion reserve area. The ecological settlement area enables development in case of increased usage density. 


\section{References}

[1] http://www.cografya.gen.tr/tr/kocaeli/iklim.html, (Access: 16/04/2019).

[2] http://www.mgm.gov.trveridegerlendirmeil-ve-ilceler-istatistik.aspxm=KOCAELI, (Access: 10/09/2019).

[3] E. Bölük, "Climate Turkey by Koppen climate classification", T. C. Ministry of Forestry and Water Affairs, General Directorate of Meteorology Research Department Climatology Branch Directorate, pp. 1-18, January, 2016.

[4] https://tr.climatedata.org/asya/tuerkiye/kocaeli/kand\%C4\%B1ra-30630/, (Access: 11/01/2019).

[5] https://kocaelibitkileri.com/\#features, (Access: 11/01/2019).

[6] https://www.haberler.com/kocaeli-deki-cevre-sorunlari-2482759-haberi/, (Access: 04/02/2019).

[7] https://www.google.com/intl/tr/earth/, (Access: 11/01/2019).

[8] J. Jäger J, "Describing Traditional Architecture In Rural Areas Examples From Syria and Jordan", Stone and Architecture, DAAD, pp. 15-25, January, 2012.

[9] M. Küçük, “An Ecological Living Unit Model for Refugee Housing Settlements in Kocaeli”, Master Thesis, Gebze Technical University, 2020.

[10] https://www.izoder.org.tr/sayfa/31/genel-bilgi-almak-istiyorum, (Access: 27/02/2019).

[11] http://portal.canovateenerji.com/tr-TR/toprak-kaynali-isi-pompasi, (Access: 30/11/2019).

[12] https://www.hydro.mb.ca/your_home/geothermal_heat_pumps/components/, (Access: 30/11/2019).

[13] http://www.artienerji.com.tr/docs/Ruzgar Enerjisi icin SSS.pdf, (Access: 30/11/2019).

[14] http://pagcev.org/geri-donusum, (Access: 16/04/2019).

[15] http://www.maden.org.tr/genel/bizden detay.php?kod =111\&tipi=5\&sube=0, (Access: 27/02/2019).

[16] Z. T. Kazanasmaz, "Evaluation of Natural Lighting Performance of Buildings", 5th National Lighting Symposium, pp. 1-12, TMMOB Chamber of Electrical Engineers, Izmir, 7-10 ${ }^{\text {th }}$ May, 2009.

[17] Z. Çetinkaya and A. Ciravoğlu, "Comparison of Sustainable Settlement Models: Eco-City and Slow City", Ideal Kent Magazine, vol. 18, pp. 8-10, 2016.

[18] M. Guzowski, "Towards Zero Energy Architecture - New Solar Energy Design”, Translated by: Tağmat T.S. and Güçmen N., YEM Publishing, Istanbul, pp: 49-58, 2010.

[19] M. Küçük, and F. Findik, "Selected Ecological Settlements". Heritage and Sustainable Development, vol. 2, no. 1, pp. 1-16, 2020. https://doi.org/10.37868/hsd.v2i1.35 